* Pós-Graduanda em Direito Privado pela ESMAM -Escola da Magistratura do Amazonas, Bacharel em Direito. E-mail: manausadvogados@hotmail.com. ** Professor Adjunto do Mestrado em Direito Ambiental da Universidade do Estado do Amazonas; Mestre em Direito Ambiental e Doutor em Direito comparado pela Universitè de Limoges/França. E-mail: v_pozzetti@hotmail.com

\section{A resolução n. 175 do CNJ e os requisitos para a celebração do casamento}

\author{
The Resolution N. 175 do CNJ OF AND \\ REQUIREMENTS FOR THE WEDDING CELEBRATION
}

\author{
Urbanete de Angiolis Silva * \\ Valmir César Pozzetti **
}

Resumo: A Resolução n. 175 do Conselho Nacional de Justiça traz alterações na estrutura jurídica brasileira e é necessário refletir sobre os requisitos legais para a celebração do casamento no Brasil. Com isso, sofremos alterações nos conceitos de família, união estável e casamento, trazendo consequências aos sujeitos da relação, gerando benefícios, direitos e obrigações outras, uma vez que a Resolução autoriza o casamento homoafetivo e, dessa forma, o contrato conjugal traz consequências às relações familiares e econômicas. Ametodologia utilizada nesta pesquisa, quanto aos fins foi a qualitativa e quanto meios foi a bibliográfica com consultas à doutrina, jurisprudência e legislação vigente.

Palavras-chaves: Conselho Nacional de Justiça. Casamento. Homoafetividade.

Abstract: The Resolution n. 175 of the National Council of Justice brings changes in Brazilian legal structure and it is necessary to reflect about the legal requirements for the marriage celebration in Brazil. With this, changes in the concepts of family, stable union and marriage are suffered, bringing consequences to the subjects of the relationship, generating benefits, rights and obligations, since the Resolution authorizes the homo affective marriage and, thereby, the conjugal contract brings consequences to the family and economical relationships. The methodology used in this research, regarding the ends was the qualitative and as means the bibliographic with queries to the doctrine, jurisprudence and actual legislation.

Keywords: National Council of Justice. Marriage. Homo Affection. 


\section{INTRODUÇÃO}

A materialização das uniões homoafetivas já ocorre há muito no Brasil. Entretanto, a falta de formalização desta união é que não permitia às pessoas nesta condição gozar da segurança jurídica a que todo cidadão brasileiro tem direito. Nesse contexto, foi editada a Resolução n. 175, de 14 de maio de 2013, pelo Conselho Nacional de Justiça que dispõe sobre a habilitação, celebração de casamento civil, ou conversão de união estável em casamento, entre pessoas do mesmo sexo, como forma de legitimar as uniões homoafetivas até então desprovidas de normatização em lei.

Desse modo, diante da omissão legislativa em regulamentar as uniões homoafetivas torna-se importante refletir sobre o alcance e porque o exame da eventual legitimidade do teor da Resolução n. 175 do Conselho Nacional de Justiça importa para a produção de conhecimento jurídico e quais as consequências e benefícios que esta legitimidade trará para a sociedade. Isto porque o conceito tradicional de família no direito brasileiro sofreu modificações profundas, uma vez que não se vincula mais para a formação de família a união entre um homem e uma mulher, o que justifica a realização de uma reflexão acerca da temática.

Assim, visando analisar de modo percuciente a matéria faz-se necessário examinar desde a natureza jurídica e objetivos do casamento, os requisitos constitucionais e legais vigentes para a sua legitimação para, por fim, analisar o teor da Resolução n. 175 do Conselho Nacional de Justiça e os novos requisitos implantados para a legitimação do casamento Brasil.

\section{NATUREZA JURÍDICA E OBJETIVOS DO CASAMENTO}

O casamento é compreendido como um contrato de natureza sui generis com o objetivo de oficializar e regulamentar a comunhão de vida do casal, a constituição de prole, a legitimação do patrimônio comum e as relações sociais.

Assim, tanto do ponto de vista doutrinário, quanto legal, no Brasil o casamento é um ato formal, solene e talvez o mais importante ato do Direito de Família, porque dele decorrem consequências jurídicas que irradiam não só no âmbito familiar, quanto no corpo social, o que justifica uma análise aprofundada do tema. 


\subsection{Conceito Histórico de Família}

Historicamente compreende-se família como o conjunto de pessoas que possuem parentesco consanguíneo, ou não, entre si e coabitam no mesmo lar. Uma família tradicional é formada pelos cônjuges unidos pelo matrimônio e pelos filhos comuns do casal que formam o núcleo familiar.

Assim, desde a Antiguidade, sob a influência do Cristianismo, no âmbito familiar a figura paterna representava a chefia do clã ou tribo, responsável pelo seu sustento e proteção, ao passo que a matriarca ficava encarregada da educação dos filhos e afazeres domésticos, o que representava a única modalidade de formação familiar legítima da época.

Desse modo, sob a influência dos dogmas católicos, a família moral e socialmente aceita era aquela oriunda do matrimônio com o propósito de procriação, com especial relevância aos filhos do sexo masculino, os quais eram os únicos beneficiários dos direitos sucessórios e encarregados da continuidade do clã, em detrimento da histórica submissão feminina no seio familiar.

Posteriormente, sob a égide do Código Civil de 1916 e ainda sob a influência religiosa, a família formada a partir do matrimônio era o único arranjo familiar legítimo com o condão da indissolubilidade, já que aquela estabelecida fora do casamento era considerada ilegítima.

Recentemente, a partir dos avanços sociais e luta de classes, vivenciados no país, a sociedade passou a reivindicar do Estado a igualdade de tratamento entre as pessoas, o respeito a liberdade sexual e a paridade de direitos entre cônjuges e filhos, conforme determina a Carta Política, in verbis:

art. $3^{\circ}$. Constituem objetivos fundamentais da República Federativa do Brasil:

\section{[...] omissis}

IV - promover o bem de todos, sem preconceitos de origem, raça, sexo, cor, idade e quaisquer outras formas de discriminação.(gn)

Neste mesmo sentido o Código Civil também reconheceu a união estável como entidade familiar: 
Art. 1723. É reconhecida como entidade familiar a união entre o homem e a mulher, configurada na convivência pública, contínua e duradoura e estabelecida com o objetivo de constituição de família.

Atualmente, do ponto de vista doutrinário, segundo Gonçalves (2012, v. 6, p. 17), família pode ser compreendida como "uma realidade sociológica e constitui a base do Estado, o núcleo fundamental em que repousa toda a organização social".

Ou seja, sociologicamente, o conceito de família independe da forma como foi constituída, quer seja oriunda do casamento, da união estável, monoparental, com ou sem filhos biológicos ou adotivos, bastando que para tanto haja afinidade entre as pessoas que a constituam e que estas se considerem parentes, ainda que por vínculos unicamente de afeto.

\subsection{Distinção entre as Modalidades de Família}

$\mathrm{Na}$ sociedade brasileira contemporânea podem ser apontadas diferentes modalidades de formação familiar, isto porque tem-se socialmente entendido que para o reconhecimento de entidade familiar não é mais necessária a diversidade de gênero.

Em síntese, a Constituição Federal de 1988, segundo Dias (2010, p. 4) "absorveu essa transformação e adotou uma nova ordem de valores, privilegiando a dignidade da pessoa humana, realizando verdadeira revolução no Direito de Família".

Desse modo, a entidade familiar ganhou enorme relevância dada sua função social, passando a ser considerada plúrima e não mais singular, na medida em que se permitem diferentes formas de constituição, tais como, família matrimonial, família formada na união estável, de relações extramatrimoniais, família monoparental, família formada pelo casal e por filhos de apenas um dos cônjuges, denominada de mosaico e família homossexual.

Assim, a partir da vigência da atual Carta Política, a família passou a ser considerada a base da sociedade, tendo especial proteção do Estado nas suas mais diferentes formas de constituição, na medida em que tem prevalecido o direito à liberdade sexual, o respeito a dignidade humana e a função social da família.

Nessa linha de ideias, Lenza (2012, p. 1213) assim se manifesta: 
O conceito de família foi ampliado pelo texto de 1988, visto que para efeito de proteção pelo Estado, foi reconhecida como entidade familiar também a união estável entre o homem e a mulher, devendo a lei facilitar sua conversão em casamento. Embora fique clara a preferência do constituinte pelo casamento entre homem e mulher (uma vez que estabelece que a lei deverá facilitar a conversão da união estável em casamento), destacamos a importância desse novo preceito constitucional (união estável), ampliando o conceito de entidade familiar.

Além disso, visando aprimorar o sistema civil anteriormente em vigor, o qual era basicamente fundado no ultrapassado modelo patriarcal e hierarquizado que até então só reconhecia a sociedade familiar formada por pai, mãe e filhos dentro das cercanias do matrimônio, o novo texto constitucional, além de reconhecer a família formada a partir da união estável, passou também a legitimar a família monoparental, ou seja, aquela formada por qualquer dos pais e seus descendentes, eliminando o preconceito existente em relação a unidades familiares constituídas por pessoas solteiras, viúvas, separadas, divorciadas e sua respectiva prole.

Com efeito, diante do prestígio dos direitos fundamentais, bem como da primazia da dignidade da pessoa humana, além do reconhecimento da igualdade entre cônjuges e de tratamento entre os filhos, no cotidiano da sociedade pós-moderna tem-se admitido tipos alternativos de convivência familiar, de modo a reconhecer direitos até mesmo às denominadas famílias mosaico.

Neste sentido, Dias (2010, p. 45) explica que família mosaico pode ser entendida como "aquelas entidades familiares formadas pela pluralidade de relações parentais, em especial as fomentadas pelo divórcio, pela separação, pelo recasamento, seguidos das famílias não matrimoniais e das desuniões".

Ademais disso, a jurisprudência do Supremo Tribunal Federal, com base nos vínculos de afetividade que une às pessoas e em respeito à dignidade humana, vem reconhecendo como família o arranjo social formado por casais homossexuais, com ou sem filhos, de modo a prestigiar a liberdade sexual e a isonomia, eliminando quaisquer resquício de preconceito ou discriminação, conforme ficou definido por ocasião do julgamento da Ação Declaratória de Inconstitucionalidade - ADI n. 4277 e Ação de Descumprimento de Preceito Fundamental - ADPF n. 132, ambas julgadas em 2011 pelo respectivo Tribunal. 
Assim, segundo Sá Neto (2011, p. 33) “é o afeto, sem sombra de dúvida, o principal fundamento das relações familiares, encontrando substrato constitucional na própria dignidade da pessoa humana".

Desse modo, qualquer que seja a forma de constituição de entidade familiar - quer seja através do casamento civil, religioso, união estável, família monoparental ou união homoafetiva - cabe ao Estado proteger a cada um de seus membros, assegurando-lhes a fruição de igualdade de direitos e deveres, em virtude do compromisso constitucional de garantir isonomia no tratamento de todos os cidadãos brasileiros.

\subsection{O Direito ao Casamento e à Procriação}

O casamento é um vínculo jurídico entre duas pessoas regulado pelas normas do Direito de Família que tem por finalidade precípua a promoção da união entre homem e mulher, de modo a regulamentar suas relações sexuais, mútua assistência e constituição de prole comum.

Neste sentido, o conceito de casamento encontra-se previsto no Código Civil Brasileiro, in verbis:

Art. 1511. O casamento estabelece comunhão de vida, com base na igualdade de direitos e deveres dos cônjuges. (BRASIL, 2002).

Neste sentido, o casamento é um dos atos jurídicos mais solenes do direito brasileiro, que exige a diversidade de sexo, o consentimento dos nubentes e a celebração na forma da lei. Entretanto, recentes decisões judiciais têm permitido a flexibilização de seus requisitos, notadamente, quando o próprio texto constitucional reconhece sua paridade com a união estável, além de admitir outras formas legítimas de constituição familiar.

Deste modo, a jurisprudência, a doutrina e os movimentos sociais vêm contribuindo para que se flexibilizem as regras atinentes ao casamento, na medida em que é direito fundamental da pessoa humana a constituição de uma família, com ou sem prole comum, cabendo ao Estado protegê-la, garantindo ao casal a livre escolha quanto à eventual procriação, se assim o desejar, não havendo legitimidade para qualquer interferência na esfera íntima da constituição da família, conforme prevê a Carta Cidadã:

Art. 226. A família, base da sociedade, tem especial proteção do Estado. (BRASIL, 1988). 
Assim, diante da primazia da dignidade da pessoa humana e das conquistas sociais alcançadas pela sociedade contemporânea não mais se sustentam argumentos históricos quanto à necessidade da observância da legalidade estrita para a fruição de efeitos advindos do casamento. Segundo Dias (2010, p. 45):

O Estado solenizou o casamento como uma instituição e o regulamentou exaustivamente. Os vínculos interpessoais passaram a necessitar da chancela estatal. É o estado que celebra o matrimônio mediante o atendimento de inúmeras formalidades. Reproduziu o legislador de 1916 o perfil da família então existente: matrimonializada, patriarcal, hierarquizada e heterossexual. Só era reconhecida a família constituída pelo casamento. O homem exercia a chefia da sociedade conjugal, sendo merecedor de respeito, devendo-lhe a mulher e os filhos obediência. A finalidade essencial da família era a conservação do patrimônio, precisando gerar filhos com força de trabalho. Como era fundamental a capacidade procriativa, claro que as famílias necessitavam ser constituídas por um par heterossexual e fértil.

Assim, sendo a preservação da intimidade um direito fundamental do indivíduo, nos termos do art. $5^{\circ}$, inciso X da Constituição da República que prevê que são invioláveis a intimidade, a vida privada, a honra e a imagem das pessoas, assegurado o direito a indenização pelo dano material ou moral decorrente de sua violação, somente à pessoa cabe a livre escolha quanto à eventual constituição de uma família advinda ou não do casamento, sendo dever do Estado garantir os meios assistenciais necessários e condignos à filiação natural ou civil.

\subsection{Planejamento Familiar: concepção natural, adoção e fertilização}

O planejamento familiar deve ser fundado nos princípios da dignidade da pessoa humana e da paternidade responsável, competindo a sua escolha ao casal, cabendo ao Estado propiciar recursos educacionais e científicos para o exercício desse direito fundamental, vedada qualquer interferência por parte de instituições oficiais ou privadas. 
Assim, segundo preconizado por Moraes (2008, p. 832) “a partir da fixação do conceito de entidade familiar, a constituição estabeleceu algumas regras de regência das relações familiares", cabendo ao Poder Público instituir, neste mister, programas e políticas públicas que visem a implementação desse direito sem, todavia, impor normas de controle de natalidade que afetem a esfera íntima do casal, a quem cabe a decisão quanto ao número de filhos que os pais desejam ter ou mesmo a abstenção em tê-los, os métodos contraceptivos a serem utilizados, o acesso a programas gratuitos de fertilização assistida a casais com dificuldades de procriação e até mesmo a opção pelo parto natural humanizado ou cesariano, de acordo com a conveniência e condições médicas da gestante.

Quanto ao princípio da paternidade responsável, Moraes (2008, p. 833) aduz:

Em face da relatividade dos direitos e garantias fundamentais e aplicandose os princípios da convivência das liberdades públicas e da concordância das normas constitucionais, não se pode deixar de observar que o texto constitucional, ao proclamar expressamente o princípio da paternidade responsável $\left(\mathrm{CF}\right.$, art. 226, parágrafo $\left.7^{\circ}\right)$, deverá ser compatibilizado com o princípio da dignidade humana $\left(\mathrm{CF}\right.$, art. $1^{\circ}$, III) durante a produção probatória para fins de investigação de paternidade, permitindo-se a realização do necessário exame de DNA, por meio de métodos não invasivos, como por exemplo, a coleta de fios de cabelo ou mesmo de saliva.

Nesse sentido, tanto a concepção natural, quanto a adoção ou mesmo fertilização assistida, são meios de procriação dos quais decorrem à filiação, que é um fato jurídico do qual irradiam inúmeros efeitos, notadamente a igualdade de direitos entre todos os filhos, cuja observância deve ser garantida pelo Estado, conforme assevera Venosa (2008, p. 211):

A procriação é, portanto, um fato natural. Sob o aspecto do Direito, a filiação é um fato jurídico do qual decorrem inúmeros efeitos. Sob perspectiva ampla, a filiação compreende todas as relações, e respectivamente sua constituição, modificação e extinção, que têm como sujeitos os pais com relação aos filhos. Portanto, sob esse prisma, o direito de filiação abrange também o pátrio poder, atualmente denominado poder familiar, que os pais exercem em relação aos filhos menores, bem como os direitos protetivos e assistenciais em geral. 
Desse modo, na atual ordem jurídica, em homenagem ao Princípio da Dignidade da Pessoa Humana, foram abolidos antigos conceitos jurídicos, tais como, filiação legítima, ilegítima ou adulterina e natural ou civil, na medida em que os filhos, independente da forma como foram concebidos método natural, fertilização assistida, inseminação artificial, adoção, decorrentes de casamento, união estável, concubinato ou até mesmo de relações incestuosas - todos, indistintamente, devem receber do Estado tratamento isonômico, no que pertine a igualdade de direitos perante a lei, ao exercício do poder familiar, dever de assistência dos pais, direitos sucessórios e outros.

\section{OS REQUISITOS CONSTITUCIONAIS E LEGAIS PARA A LEGITIMAÇÃO DO CASAMENTO}

O casamento, enquanto ato jurídico solene, exige a realização de um rito procedimental prévio, a fim de que seja reconhecido pela ordem jurídica. Assim, além da convivência em comum, cabe aos nubentes habilitarem-se perante a autoridade competente, juntando a documentação de caráter pessoal necessária, a qual será rigorosamente analisada, para só então formalizarem o ato perante o juiz de direito ou juiz de paz.

\subsection{Casamento}

O casamento é um contrato jurídico entre as partes contratantes e, como todo contrato traz um objeto e obrigações aos contratantes.

A tipificação legal do casamento, enumerando os requisitos sobre o gênero, está no Código Civil, in verbis:

Art.1565. Pelo casamento, homem e mulher assumem mutuamente a condição de consortes, companheiros e responsáveis pelos encargos da família. (BRASIL, 2002).

De acordo com a legislação civil brasileira vários são os requisitos para a celebração e validade do casamento no país. Desse modo, devem ser observadas formalidades legais desde o processo de habilitação para o casamento, comprovação de capacidade para o matrimônio ou suprimento judicial de consentimento dos representantes legais no caso de nubente 
incapaz, inexistência de impedimentos - basicamente ligados a consanguinidade, afinidade e adoção, impedimento resultante de casamento anterior e impedimento decorrente de crime - enfim, celebração realizada nos termos da lei.

Segundo Gonçalves (2012, p. 141) "para que o casamento exista, é necessária a presença dos elementos essenciais ou estruturais: diferença de sexo, consentimento e celebração na forma da lei".

Assim, o casamento tradicionalmente legitimado, tanto pela Constituição Federal, quanto pelo Código Civil, exige a incidência de elementos essenciais, notadamente, a diversidade de sexo. Logo a diversidade de sexo seria essencial para a existência ou mesmo validade do casamento, a despeito da inexistência de expressa previsão legal, conforme assevera Gonçalves (2012, p.142):

Ainda de forma indireta, a Constituição Federal, ao reconhecer a união estável "entre homem e a mulher como entidade familiar, devendo a lei facilitar sua conversão em casamento", e ao proclamar que "os direitos e deveres referentes à sociedade conjugal são exercidos igualmente pelo homem e pela mulher" (art. 226, parágrafo $3^{\circ}$ e $5^{\circ}$ ), só admite casamento entre pessoas que não tenham o mesmo sexo. Esse posicionamento é tradicional e já era salientado nos textos clássicos romanos.

Todavia, mesmo diante do texto legal e posições doutrinárias, a jurisprudência brasileira passou nos últimos anos a mitigar a diversidade de sexo para o reconhecimento de direitos previdenciários e patrimoniais em uniões homoafetivas, de modo a afastar a incidência de qualquer discriminação quanto à identidade de gênero, o que rende ensejo a constantes divergências doutrinárias, em face da efervescência social do tema.

\subsection{União Estável}

Historicamente, as relações familiares sempre foram pautadas muito mais pela vontade livre e consciente das pessoas do que propriamente pelo modelo tradicional formada a partir do casamento, conforme exigido na lei.

Assim, surge a união estável como entidade familiar formada a partir da convivência pública, contínua e duradoura entre um homem e uma mulher com objetivo de constituição de uma família, independentemente da formalização do casamento. 
Desse modo, a nova ordem jurídica focada na supremacia da dignidade da pessoa humana e nos direitos fundamentais dispõe no texto da Constituição da República, in verbis:

Art. $226(\ldots)$ omissis

(...) omissis

$\S 3^{\circ}$. Para efeito de proteção do Estado, é reconhecida a união estável entre o homem e a mulher como entidade familiar devendo a lei facilitar sua conversão em casamento; (BRASIL, 1988).

Neste sentido, a convivência marital, independente de matrimônio, antes socialmente discriminada, passou a receber tratamento constitucional paritário ao casamento, de modo a garantir direitos e deveres aos companheiros, em virtude de seu reconhecimento como legítima entidade familiar.

Posteriormente, o conceito de União Estável foi disciplinado pelo disposto no art. $1^{\circ}$ da Lei n. 9.278/96, in verbis:

Art. $1^{\circ}$. É reconhecida como entidade familiar à convivência duradoura, pública e contínua de um homem e uma mulher, estabelecida com o objetivo de constituição de família. (BRASIL, 1996).

Recentemente, ao ser instado através da Ação Declaratória de Inconstitucionalidade - ADI n. 4277 e Ação de Descumprimento de Preceito Fundamental-ADPF n. 132 acerca da possibilidade jurídica de se reconhecer a União Estável independente da diversidade sexual entre os companheiros, o Plenário do Supremo Tribunal Federal foi categórico no sentido de negar vigência a qualquer interpretação do art. 1723 do Código Civil que impedisse o reconhecimento às uniões homoafetivas como entidade familiar, ou seja, como união estável com a mesma paridade de direitos àquelas constituídas entre homem e mulher, na medida em que o ordenamento constitucional não se coaduna com quaisquer espécie de discriminação.

Assim, conquanto o texto constitucional e a legislação ordinária preconizem a União Estável como entidade familiar a partir da comunhão de vidas entre homem e mulher, a jurisprudência da Suprema Corte brasileira, conforme as citadas ações de controle abstrato, ao avaliar a legislação, 
resolveu dar interpretação conforme a Constituição, vedando qualquer discriminação em virtude de sexo, cor ou raça por entender que ninguém pode ser diminuído ou discriminado em função de sua preferência sexual.

Desse modo, embora remanesça na legislação brasileira a necessidade da diversidade sexual para o reconhecimento da União Estável, o Supremo Tribunal Federal, em decisão unânime e com eficácia erga omnes no ano de 2011 no julgamento da ADI n. 4277 e ADPF n. 132, estendeu o reconhecimento dos mesmos direitos e deveres entre companheiros heterossexuais às uniões homoafetivas, o que significou um importante avanço para esta modalidade de entidade familiar até então legalmente marginalizada e tratada com desigualação jurídica.

\subsection{Casamento como instituto de promoção à dignidade da pessoa humana}

Uma das principais finalidades do matrimônio é o estabelecimento de uma comunhão plena de vida entre os conjugês, com direito e deveres a ambos.

A tipificação legal desta comunhão plena, é oferecida pelo Código Civil, in verbis:

Art. 1511. O casamento estabelece comunhão plena de vida, com base na igualdade de direitos e deveres dos cônjuges. (BRASIL, 2002).

Desse modo, apesar de existirem diferentes modalidades de constituição de uma entidade familiar, o casamento, enquanto ato jurídico solene devidamente celebrado, ainda guarda certa proeminência sociológica e jurídica, na medida em que oficializa a comunhão de vida do casal, possibilitando a constituição de uma família e, consequentemente, promovendo a dignidade humana de seus membros.

Nesse sentido, os laços que unem os membros de uma família vão muito além da mera consanguinidade, isto porque é a afetividade que harmoniza as relações familiares, perenizando vínculos de estreitamento emocional, para além de meras relações econômicas ou patrimoniais.

Em síntese, a família é identificada pelo afeto que aproximou o casal a partir da união, o que dá a exata dimensão da condição humana, razão 
pela qual deve merecer do Estado especial proteção. Isto porque é a convivência diária, em virtude da origem comum ou por mera afinidade dos membros de uma família que torna possível a comunhão de vidas, da qual decorrem variados efeitos morais, patrimoniais ou econômicos, cujo conteúdo não está disciplinado pelo Direito.

Assim, a proteção conferida pelo Estado ao casamento, envolvendoo em requisitos de extrema solenidade, visam garantir a legitimidade do ato jurídico celebrado, na medida em que do referido ato advirão efeitos, tais como: direitos e deveres de repercussão não só de interesse dos membros da família constituída, mas reflexos sociais de significativa relevância, razão pela qual, doutrinariamente, o casamento ainda é considerado o centro do Direito de Família por ser um instituto capaz de promover a dignidade humana.

Em síntese, ao disciplinar o casamento como primeira modalidade de formação familiar, o legislador constituinte visou preservar a dignidade da pessoa humana, inclusive com estímulo ao reconhecimento de efeitos civis do casamento religioso, igualdade de direitos e deveres entre cônjuges, planejamento familiar, incentivo a paternidade responsável e proteção contra a violência doméstica, o que reflete os valores vigentes na sociedade, os quais não podem ser ignorados na interpretação da lei. Ou seja, apesar de não ser a única forma de constituição familiar, o casamento ainda continuou sendo alvo de rigorosa normatização, tanto por parte da Carta Cidadã, quanto pelo Código Civil.

\subsection{Diversidade sexual e casamento homoafetivo}

Ao longo do processo civilizatório, a diversidade sexual sempre foi considerada como um requisito necessário à validade da celebração do casamento, na medida em que representava um dogma religioso intransponível e de observância obrigatória na cultura ocidental, em virtude de a perpetuação da espécie e a prole contribuírem para o simbolismo da virilidade masculina.

De igual sorte, a atual lei civil brasileira, apesar de não ter sido expressa neste sentido exige, implicitamente, por ocasião do processo de habilitação, que os nubentes comprovem a diversidade sexual, cuja omissão poderá resultar na anulabilidade do ato, em virtude de erro essencial sobre a pessoa 
no que diz respeito à sua identidade ou até mesmo a inexistência do ato, por falta de requisito essencial. Vejamos o texto legal:

Art. 1556. O casamento pode ser anulado por vício de vontade, se houve por parte de um dos nubentes, ao consentir, erro essencial quanto à pessoa do outro. (BRASIL, 2002).

Ocorre que, a partir de um enfoque valorativo fulcrado no respeito à preservação da intimidade, da liberdade sexual e na vedação à discriminação e ao preconceito em virtude de orientação sexual foram sendo agregados outros valores a esta premissa, na medida em que o sexo, salvo exceções legais, não pode ser usado como mecanismo para desigualação jurídica.

Assim, a exigência da diversidade de gênero para a celebração do casamento, a exemplo do que ocorreu com a União Estável vem, paulatinamente, sendo mitigada pelo clamor de uma sociedade pós-moderna mais afinada com a universalização dos direitos humanos e que prega a tolerância entre os diferentes grupos sociais, em detrimento da discriminação negativa deliberada o que vem ressoando positivamente em recentes decisões dos tribunais brasileiros.

Neste sentido, a sociedade brasileira é plural e como tal deve garantir a igualdade de direitos de seus membros, conforme destaca Dias (2013, p. 171):

A decisão do Supremo, com certeza, é um marco da nossa sociedade, mostra que a Justiça, de fato, não é cega. Ela aplicou a Constituição, ela foi chamada a julgar em face de uma omissão do nosso legislador. E fez o que tinha que ser feito: dizer que vivemos numa sociedade livre, igual, que respeita a dignidade da pessoa e o amor delas.

Logo, a partir de uma interpretação axiológica, apesar de a decisão referida ter sido proferida por ocasião do julgamento da Ação Declaratória de Inconstitucionalidade - ADI n. 4277 e Ação de Descumprimento de Preceito Fundamental - ADPF n. 132, nas quais se discutia a legitimidade do reconhecimento de uniões homoafetivas como entidades familiares, resta defensável a ampliação do raciocínio para o caso de casamento homoafetivo, na medida em que a omissão legislativa quanto ao enfrentamento da matéria, não pode ser usada como escudo à manutenção de discriminações desarrazoadas e vedadas pelo texto constitucional. 


\section{A RESOLUÇÃO N 175 DO CNJ E OS REQUISITOS LEGAIS PARA O CASAMENTO NO BRASIL}

O Conselho Nacional de Justiça é órgão do Poder Judiciário que, dentre suas funções, está a de regulamentar atos cartorários. Desse modo, valendo-se de tal prerrogativa, tem o aludido Conselho estabelecido normas de funcionamento dos Cartórios com vistas a uniformizar o atendimento à população em todo o território nacional.

Assim, diante da omissão legislativa, recentemente o Conselho Nacional de Justiça publicou regulamentação, possibilitando a realização de casamento entre pessoas do mesmo sexo, o que rendeu ensejo a divergência não só entre os membros do próprio Órgão, quanto na classe jurídica e sociedade em geral, diante da suposta usurpação de competência legislativa.

\subsection{Resolução $n^{0} 175$ do CNJ e Invasão da Competência Legislativa?}

Visando coibir qualquer resquício de discriminação e promover a cidadania em igualdade de condições, o Conselho Nacional de Justiça órgão do Poder Judiciário criado pela Emenda Constitucional n. 45/2004 no exercício fiscalizatório e disciplinar das atividades cartorárias no país, tomou a iniciativa de publicar a Resolução n. 175 de 14 de maio de 2013, que dispõe sobre a habilitação, celebração de casamento civil, ou de conversão de União Estável em casamento entre pessoas do mesmo sexo, determinando que os Cartórios Extrajudiciais brasileiros assim passassem a proceder, abstendo-se de causar embaraços a quem deseje legitimar tais atos jurídicos, sob pena de responsabilidade correicional.

Conforme os anais do Conselho Nacional de Justiça, por ocasião da votação para a aprovação da citada norma regulamentadora houve divergência dentro do próprio Colegiado, a exemplo da Conselheira Maria Cristina Peduzzi que votou contra a aprovação da Resolução, alegando que o Congresso Nacional deveria primeiro aprovar Projeto de Lei sobre o assunto antes da regulamentação pelo Conselho Nacional de Justiça.

Em idêntico sentido posicionou-se na referida sessão o SubprocuradorGeral da República em atuação perante o Conselho Nacional de Justiça, Francisco Sanseverino, quando da edição da noticiada Resolução, aduzindo, em síntese, que o texto extrapolava as competências do órgão, na medida 
em que disciplinava matéria de competência legislativa, além de estender legitimidade ao casamento entre pessoas do mesmo sexo, apesar de o Supremo Tribunal Federal haver manifestando-se, exclusivamente, em relação à União Estável, por ocasião do julgamento das ações de controle abstrato de constitucionalidade (ADI n. 4277 e ADPF n. 132).

Contudo, o Presidente do Conselho Nacional de Justiça e autor da proposta da Resolução, Ministro Joaquim Barbosa, enfatizou durante a sessão de apreciação da norma pelo Colegiado que seria um contrassenso esperar o Congresso Nacional analisar o tema para se dar efetividade a decisão do Supremo Tribunal Federal, uma vez que ao deferir a possibilidade jurídica de reconhecimento de união estável entre parceiros homossexuais, estarse-ia diante de idêntico tratamento quanto ao casamento, na medida em que o texto constitucional veda qualquer forma de discriminação.

Nesta linha de ideias, torna-se imprescindível analisar a possibilidade de se considerar legítima ou não a atuação do Conselho Nacional de Justiça ao normatizar administrativamente tão polêmica matéria, independente de lei ordinária sobre o tema, cotejando com o pretensa invasão de competência legislativa, na medida em que a regulamentação das uniões homossexuais se apresenta como uma realidade social inadiável, que reclama uma atuação proativa do Poder Judiciário, uma vez que, se de um lado o legislador é omisso, ao Estado-Juiz é vedada a utilização do Princípio do Non Liquet, previsto nos termos do art. 126 do Código de Processo Civil para eximir-se de julgar e, consequentemente, garantir dignidade às pessoas, in verbis:

Art. 126. O juiz não se exime de sentenciar ou despachar alegando lacuna ou obscuridade da lei. No julgamento da lide caber-lhe-á aplicar as normas legais; não as havendo, recorrerá à analogia, aos costumes e aos princípios gerais do direito. (BRASIL, 2002).

Assim, vale ressaltar que a isonomia prevista no caput do art. $5^{\circ}$ da Constituição da República, enquanto norma definidora de direito fundamental, tem aplicabilidade imediata, nos termos do parágrafo $1^{\circ}$ do mencionado art. $5^{\circ}$ da Carta Política, razão pela qual torna-se de rigor asseverar não ter havido invasão de competência por parte do Conselho Nacional de Justiça ao editar a aludida norma regulamentadora da atividade cartorária. Vejamos a norma constitucional: 
Art. $5^{\circ}$. Todos são iguais perante a lei, sem distinção de qualquer natureza, garantindo-se aos brasileiros e aos estrangeiros residentes no País a inviolabilidade do direito à vida, à liberdade, à igualdade, à segurança e à propriedade, nos termos seguintes:

$\S 1^{\circ}$. As normas definidoras dos direitos e garantias fundamentais têm aplicação imediata. (BRASIL, 1988).

Ademais, é a própria Constituição da República que veda a discriminação de gêneros e, portanto, ao publicar a referida Resolução, o Conselho Nacional de Justiça apenas usou de seu poder regulamentar conferido pela Constituição Federal para dar a máxima aplicabilidade à norma constitucional, abolindo quaisquer resquícios de desigualação jurídica com base na identidade de sexo.

\subsection{Uniões Homoafetivas: a jurisprudência dos Tribunais Superiores}

Diante do quadro fático e jurígeno delineado é oportuno asseverar que a jurisprudência dos Tribunais Superiores, tanto do STJ, quanto do STF passou a garantir a igualdade de direitos e deveres em se tratando de uniões homoafetivas, em homenagem à máxima eficácia dos direitos fundamentais.

No início do ano 2000, começou a intensificar nos Tribunais Superiores brasileiros o fluxo de demandas relativas a direitos previdenciários e sucessórios envolvendo união entre pessoas do mesmo sexo, (cf. Resp 395904/RS (200101897422) RE 664353, 13-12-2005, 6ª Turma - Rel. Min. Hélio Quaglia Barbosa) o que geralmente era palco para acirradas discussões judiciais, na medida em que não havia consenso quanto a paridade de direitos entre casais héteros e homoafetivos, em virtude do silêncio legislativo quanto ao tema.

Contudo, nessas demandas iniciais já havia um implícito clamor de não apenas serem reconhecidos reflexos patrimoniais relativos às sociedades de fato, mas o anseio de que os direitos questionados ganhassem maior amplitude, o que daria uma feição humanizada à questão posta em juízo, a partir de uma exegese constitucional mais consentânea com a pluralidade da sociedade brasileira.

Nesse sentido Dias (2010, p. 87) já se posicionava: 
Simplesmente encobrir a realidade não irá solucionar as questões que emergem quando do rompimento das relações que, mais do que sociedades de fato, constituem sociedades de afeto, o mesmo liame que enlaça os parceiros heterossexuais. Necessário é encarar a realidade, pois descabe estigmatizar quem exerce orientação sexual diferente.

Assim, diante das inúmeras transformações pelas quais tem passado a sociedade pós-moderna, marcada pelo direito à livre manifestação do pensamento e pelas liberdades públicas em geral, bem como pela velocidade da informação e ainda fulcrada nos movimentos sociais que têm reivindicado com maior consistência a implementação de políticas públicas em favor das minorias, tornou-se ponto pacífico na jurisprudência brasileira o reconhecimento de direitos e deveres oriundas das relações homoafetivas, como mecanismo de inclusão social e cidadania.

Aliás, corroborando com o exposto, urge enfatizar que o Superior Tribunal de Justiça por ocasião do julgamento do REsp 1.183.378/RS asseverou inexistir óbices legais à celebração de casamento entre pessoas do mesmo sexo, o que seguramente serviu de base ainda para a edição da Resolução n. 175 do Conselho Nacional de Justiça que passou a disciplinar detalhadamente à matéria.

\subsection{A amplitude e consequências da Resolução nº 175 do CNJ}

Com a edição da Resolução n. 175 do Conselho Nacional de Justiça muitas dúvidas surgiram, bem como muitas discussões jurídicas a respeito do reflexo e alcance da Resolução que dispõe sobre a habilitação, celebração de casamento civil, ou conversão de união estável em casamento, entre pessoas do mesmo sexo.

Nesse norte, a citada Resolução proíbe às autoridades competentes de recusarem à habilitação, celebração de casamento civil ou conversão de União Estável em casamento entre pessoas do mesmo sexo, e ainda dispõe que a eventual recusa ao cumprimento da respectiva norma importará em responsabilidade correicional do servidor faltoso.

Assim, diante da norma regulamentadora, dirigida aos cartorários brasileiros é defensável asseverar que, em termos práticos, a Resolução autoriza a habilitação e realização do casamento homoafetivo ou até mesmo 
conversão de União Estável em casamento, de cujo ato jurídico, advirão todos os direitos inerentes ao matrimônio convencional.

Insta destacar que o Ativismo Judicial ao editar esta Resolução expõe implicitamente a omissão do Poder Legislativo em disciplinar a matéria, em virtude de convicções religiosas ou ideológicas que até então impediam a efetivação do direito ao casamento às minorias homoafetivas. Ou seja, sociologicamente, o texto da Resolução afasta o preconceito e a homofobia ainda arraigados em grande parte das lideranças parlamentares brasileiras, numa tentativa de erradicar a desigualação jurídica em razão de orientação sexual, conforme prevê a Carta Cidadã.

Assim, ao autorizar o casamento civil entre pessoas do mesmo sexo e, consequentemente, a fruição de todos os seus efeitos sociais, pessoais e patrimoniais, além dos deveres recíprocos dos cônjuges - fidelidade recíproca, vida em comum no domicílio conjugal, mútua assistência, sustento, guarda e educação dos filhos, respeito e considerações mútuos, dentre outros - certamente, a novel regulamentação prestigiou o afeto, a função social da família, o respeito as liberdades individuais e, sobretudo, a dignidade da pessoa humana, valores essenciais a qualquer sociedade que se intitule civilizada e justa.

\subsection{O direito ao planejamento familiar por dasais homoafetivos: adoção e fertilização}

Do mesmo modo que a família formada por casais heterossexuais, os casais homoafetivos têm direito ao planejamento familiar, ou seja, a constituição de uma família com prole comum, quer por meio de adoção conjunta ou fertilização assistida ou in vitro, cabendo ao Estado propiciar os recursos médicos e científicos para o exercício desse direito, vedada qualquer forma coercitiva por parte de instituições oficiais ou privadas.

No que pertine à adoção de filhos por homossexual, em se tratando da modalidade individual, há muito esta modalidade vem sendo admitida pelos tribunais brasileiros, mediante o preenchimento dos requisitos legais comuns à adoção e desde que também o estudo psicossocial realizado pela equipe multidisciplinar prevista no Estatuto da Criança e do Adolescente revele que a medida será benéfica à criança ou adolescente. 
Contudo, embora a legislação civil não trate da adoção conjunta por casais homoafetivos, a jurisprudência vem se firmando no sentido de admitila, a exemplo de vários julgados oriundos do Tribunal de Justiça do Rio Grande do Sul, posicionamento este sancionado pelo Superior Tribunal de Justiça, nos seguintes termos:

Anote-se, então, ser imprescindível, na adoção, a prevalência dos interesses dos menores sobre quaisquer outros, até porque se discute o próprio direito à filiação, com consequências que se estendem por toda a vida. Decorre daí que, também no campo da adoção na união homoafetiva, a qual como realidade fenomênica, o Judiciário não pode desprezar, há que se verificar qual a melhor solução a privilegiar a proteção aos direitos da criança. Na específica hipótese, há consistente relatório social lavrado por assistente social favorável à adoção e conclusivo da estabilidade da família, pois é incontroverso existirem fortes vínculos afetivos entre a requerente e as crianças. Assim, impõe-se deferir a adoção lastreada nos estudos científicos que afastam a possibilidade de prejuízo de qualquer natureza às crianças, visto que criadas com amor." (Resp 889.852-RS, $4^{\mathrm{a}}$ T., rel. Min. Luis Felipe Salomão, j. 27-4-2010).

Assim sendo, o direito à formação de uma família independe da orientação sexual de seus membros, visto que a isonomia preconizada pelo texto constitucional não se submete à exclusividade da heterossexualidade. Aliás, em se tratando de adoção haverá sempre como requisito indispensável a observância do melhor interesse do infante e a tutela de seus direitos, em ordem de prioridade absoluta, razão pela qual a colocação nesta modalidade de família substituta terá esta orientação, quer seja numa família convencional, quer seja numa família homoafetiva.

Cabe ainda ressaltar que muitos casais homoafetivos têm se valido da fertilização assistida ou mesmo in vitro, utilizando material genético próprio ou de doadores anônimos, para realizar o sonho da paternidade/ maternidade, o que tem encontrado amparo nas normas expedidas pelo Conselho Federal de Medicina, na medida em que tais procedimentos são realizados por profissionais da área médica ou geneticista sem que se infira quanto à eventual orientação sexual dos progenitores. Vejamos o posicionamento do Conselho Federal de Medicina sobre normas éticas para a utilização das técnicas de reprodução assistida (RA) por casais homoafetivos, estabelecidas na Resolução n. 2013/2013: 
II - Pacientes das Técnicas de RA:

1- Todas as pessoas capazes, que tenham solicitado o procedimento e cuja indicação não se afaste dos limites desta resolução, podem ser receptoras das técnicas de RA desde que os participantes estejam de inteiro acordo e devidamente esclarecidos sobre a mesma, de acordo com a legislação vigente.

2- É permitido o uso das técnicas de RA para relacionamentos homoafetivos e pessoas solteiras, respeitado o direito da objeção de consciência do médico. (CONSELHO FEDERAL MEDICINA, 2013)

Quanto aos procedimentos cartorários inerentes ao registro de nascimento de crianças adotadas ou biologicamente concebidas por casais homoafetivos, tem prevalecido o seguinte entendimento no Superior Tribunal de Justiça:

Anote-se, então, ser imprescindível, na adoção a prevalência dos interesses dos menores sobre quaisquer outros, até porque se discute o próprio direito de filiação, com consequências que se estendem por toda a vida. Decorre daí, que também no campo da adoção na união homoafetiva, a qual, como realidade fenomênica, o Judiciário não pode desprezar, há que se verificar qual a melhor solução a privilegiar a proteção aos direitos da criança. Frise-se aqui inexistir expressa previsão legal a permitir também a inclusão, como adotante, do nome da companheira de igual sexo nos registros de nascimento das crianças, o que já é aceito em vários países, tais como a Inglaterra, País de Gales, Países Baixos, e em algumas províncias da Espanha, lacuna que não se mostra como óbice à proteção proporcionada pelo Estado aos direitos dos infantes. (Resp 889.852-RS, Rel. Min. Luís Felipe Salomão, julgado em 27/04/10).

Dessa forma, com amparo na citada jurisprudência do Superior Tribunal de Justiça é defensável inferir que no caso de adoção por casais homoafetivos o assento de nascimento deverá reproduzir a realidade dos fatos, ou seja, com a inserção dos nomes de dois pais ou duas mães, isto porque busca-se tratar com respeito e naturalidade a formação familiar do adotando, o qual passará a usufruir de todos os direitos inerentes à novel filiação a partir do momento em que tenha a oficialização do ato consolidado no seu registro civil. 


\section{CONCLUSÃO}

Com efeito, pode-se concluir que, efetivamente, o Conselho Nacional de Justiça ao editar a Resolução n. 175, que dispõe sobre a habilitação, celebração de casamento civil, ou conversão de União Estável em casamento, entre pessoas do mesmo sexo não usurpou da competência do Poder Legislativo, na medida em que visou, unicamente, regulamentar com isonomia questões sociais até então ignoradas pelo Parlamento brasileiro e que encontram-se dentro da esfera de competência regulamentar daquele órgão jurisdicional.

Vale ressaltar que as atribuições constitucionalmente atribuídas ao Conselho Nacional de Justiça admitem que o órgão não só fiscalize as atividades cartorárias, mas que edite resoluções que visem normatizar e uniformizar os serviços de todos os cartórios brasileiros, de modo que seja garantida a segurança jurídica dos atos notariais.

Assim, ao regulamentar o casamento homoafetivo, mais que cumprir um dever formal, o Conselho Nacional de Justiça propiciou a paridade de tratamento entre os cidadãos brasileiros, prestigiando valores fundamentais como a dignidade da pessoa humana, a função social da família e o afeto, abolindo o arbítrio da desigualação jurídica desarrazoada e unicamente fulcrada no preconceito de gênero e na marginalização das minorias o que não condiz com atual estágio de desenvolvimento da sociedade pós-moderna e nem com a ordem constitucional vigente.

Desse modo, ressaltou-se a importância que deve ser dada a uma leitura atualizada da Constituição Federal, o que vem sendo realizado pelos Tribunais Superiores e por órgãos como o Conselho Nacional de Justiça que, ao adotar posições desta jaez, reforçam que a aplicabilidade da norma não pode ser desvinculada da realidade social, mas, sobretudo, comprometida com a universalização da igualdade e propulsão dos direitos humanos, garantindo aos casais homoafetivos não só a legalização e valorização desta união através do casamento, mas também a justa distribuição dos bens econômicos conquistados em comum, bem como o direito de ter um lar harmonioso, habitado pelo afeto entre cônjuges e pela alegria da presença de uma criança, legando aos casais nesta condição o direito de exercer com plenitude o direito de formar uma família. 


\section{REFERÊNCIAS}

BRASIL. Constituição (1988). Constituição da República Federativa do Brasil. Brasília, 1988 .

. Lei n. 10.406, de 10 de janeiro de 2002. Institui o Código Civil. Brasília, 2002.

. Lei n. 3.071, de 1 de janeiro de 1916. Brasília, 1916.

. Lei n. 9.278, de 10 de maio de 1996. Regula o $\S 3^{\circ}$ do art. 226 da Constituição Federal. Brasília, 1996.

. Resolução n. 175, de 14 de maio de 2013. Dispõe sobre a habilitação, celebração de casamento civil, ou de conversão de união estável em casamento, entre pessoas de mesmo sexo. Brasília, 2013.

CONSELHO FEDERAL MEDICINA. Resolução CFM n. 2.013/ 2013. Adota as normas éticas para a utilização das técnicas de reprodução assistida, anexas à presente resolução, como dispositivo deontológico a ser seguido pelos médicos e revoga a Resolução CFM n ${ }^{\circ}$ 1.957/10. 2013.

DIAS, Maria Berenice. Manual de direito das famílias. São Paulo: RT, 2010.

. Não há obstáculo legal para o casamento gay. Disponível em: $<\mathrm{http}$ ://mariaberenice.com.br/pt/berenice-dias - nao-ha-obstaculo-legalpara-o-casamento-gay.cont.htm>. Acesso em: 22 ago. 2013.

GONÇALVES, Carlos Roberto. Direito civil brasileiro. São Paulo: Saraiva, 2012. v.6.

LENZA, Pedro. Direito constitucional esquematizado. São Paulo: Saraiva, 2012.

MORAES, Alexandre de. Direito constitucional. São Paulo: Atlas, 2008. 
SÁ NETO, Clarindo Epaminondas de. O princípio da afetividade como norte do direito de família no ordenamento jurídico brasileiro.

Disponível em: $<$ http://www.portalmultipla.com.br/i/f/\%7BFCA2F0BEEAF5-4F58-82B2-C62A281C427B\%7D_Clarindo_\%20Neto.pdf>. Acesso em: 15 jan. 2012.

VENOSA, Sílvio de Salvo. Direito civil. São Paulo: Atlas, 2008. v. 6.

Artigo recebido em 01/10/13 e aprovado para publicação em 12/11/13

Como citar: POZZETTI, Valmir César; SILVA, Urbanete de Angiolis. A resolução n. 175 do $\mathrm{CNJ}$ e os requisitos para a celebração do casamento. Scientia Iuris, Londrina, v.17, n.2, p.107-130, dez.2013. DOI: 10.5433/21788189.2013v17n2p107. 